\title{
THE MISES-HAYEK BUSINESS CYCLE THEORY
}

\author{
ROBYN HARTE-BUNTING*
}

Resumen: El artículo es una visión general de la Teoría Austriaca del Ciclo Económico (TACE) basada en un primer contacto con la literatura. La TACE se presenta en términos de los fenómenos que intenta explicar: crisis económicas, concentradas en el sector bancario. Después se expone una breve investigación de las semejanzas y diferencias entre Mises y Hayek, los principales contribuyentes a la TACE. El trabajo concluye con unas recomendaciones de política económica que se analizan a la luz de la TACE.

Palabras clave: Crisis Financiera, Ciclo Económico, Inflación, Ahorro.

Clasificación JEL: B53, E42, E44, E61, G01, G21, P10, P20.

Abstract: The Paper is an Overview of Austrian Business Cycle Theory (ABCT) phenomena it is intended to explain, economy wide crisis especially concentrated on the banking sector. A short examination of similarities and differences between Mises and Hayek, the main developers of $A B C T$, is then given. Finally, some policy recommendations are examined in the light of $A B C T$.

Key words: Financial Crisis, Business Cycle, Inflation, Saving.

JEL Classification: B53, E42, E44, E61, G01, G21, P10, P20.

\section{I \\ INTRODUCTION}

The Austrian School of Economics has contributed vastly to the body of knowledge of society. We can mention the subjective theory of value, its insights into the nature of our most important

\footnotetext{
* Master and PhD. Candidate in Economics of the Austrian School. Vega Agency, Vodni 1, Brno 60200. Czech Republic. Phone-00420 608211686.
} 
knowledge as being inarticulate and dispersed, its account of methodology in economics and the improper use of mathematics by modern economists, and so on. However, I believe that the most pertinent, urgent and important contributions of the school in this era are twofold-firstly, that it is impossible to make economic calculations under central planning or socialism, this latter term understood as defined by Jesús Huerta de Soto as «any system of institutional aggression on the free exercise of human action or entrepreneurship.» (Huerta de Soto [2005] p. 4). Secondly, its development of Austrian Business Cycle Theory, an extremely powerful analytical framework for understanding the characteristic of repeated economic booms and subsequent busts which have plagued developed economies since at least the early $19^{\text {th }}$ Century, and which are typically believed to be caused by inherent instability in the processes of free market capitalism. (We shall see that nothing could be further from the truth).

As we shall see, central to this theory is a full understanding of the nature, causes and consequences of inflation: it is perhaps only by the time we reach our conclusion that the reader will see why I believe that this central concept is of the utmost urgency to understand and counteract in reality, and why inflation threatens society itself. I therefore believe that it is entirely appropriate to include this theory as one of the two most important contributions of the Austrians to the modern world.

Huerta de Soto emphasises these points:

... now that the theoretical gap represented by the analysis of socialism has been covered perhaps... the most significant field is the monetary one.

... social relations in which money is involved are by far the most abstract and difficult to understand... (Huerta de Soto [2009] p. 139).

As I develop this theme, I hope to show that ABCT is in fact a special case of the errors and damage inflicted on the economy by socialism, as defined above. This very point has been made by Huerta de Soto and it is worth quoting him in full. In Money, bank Credit, and Economic Cycles, an 884 page book in the 
English translation devoted entirely to ABCT, Huerta de Soto notes:

... business cycles are a practical example of the errors in economic calculation which result from state interventionism in the economy (in this case in the monetary and credit fields)... in other words, we could consider the entire contents of this book as simply the application of the theorem of the impossibility of socialist economic calculation to the particular case of credit and the financial sector. (Huerta de Soto [2008] p. 377 Fn. 86).

\section{What is $\mathrm{ABCT}$ trying to explain?}

The most direct way to understanding a theory is by focusing on exactly that which it is a theory of; in other words, what problem is it trying to resolve or fully understand, what phenomena is it trying to give an account of?

We have already noted that ABCT is an explanation of the widely experienced boom/bust cycle. Roger Garrison describes it as «a theory of unsustainable boom». (Garrison [2004] p. 323).

However, I think the essence of what ABCT addresses has never been stated more sharply than by Murray Rothbard in his America's Great Depression.

Rothbard first recognises that business must, by its nature, deal with a great deal of change that is not forecastable and that sometimes these changes are adverse, leading to ruin or capital loss in one or many sectors of industry; we can think of war, earthquakes, crop failures or indeed new technologies, very successful harvests depressing prices, industrial accidents and so on.

We may therefore expect specific business fluctuations all the time. There is no need for any special theory to account for them. (Rothbard [2005] p. 6).

But there is need to account for the distinguishing feature of the type of crisis that $\mathrm{ABCT}$ seeks to understand: 
Declines in specific industries can never ignite a general depression. Shifts in data will cause increases in activity in one field, declines in another. There is nothing here to account for a general business depression, a phenomenon of the true «business cycle». (Rothbard [2005] p. 6).

In other words:

Business moves along nicely with most businesses making handsome profits. Suddenly, without warning, conditions change and the bulk of business firms are experiencing losses, they are suddenly revealed to have made grievous errors in forecasting. (Rothbard [2005] p. 8).

Hence «The explanation of depressions, then, will not be found by referring to specific or even general business fluctuations per se. The main problem that a theory of depression must explain is: why is there a sudden general cluster of business errors?» (Rothbard [2005] p. 8).

And although Rothbard notes that any BCT (business cycle theory) must also explain other typical features of such an event, such as the disparity between fluctuations in capital goods versus consumer goods industries during economic contraction (Rothbard [2005] p. 9), the sudden and widespread revelation of business error is the essential phenomenon that requires explanation.

\section{Literature and Strategy}

In this final part of the introduction, I would like to include a short note on the literature I have used to write this paper and the underlying context of my strategy in presenting it. A full bibliography is given later but it is worth noting Roger Garrison's remark that:

This understanding of the market processes that takes the economy through boom and bust has come piecemeal and in a leapfrog progression in the writings of Mises and Hayek. (Garrison [2004] p. 323). 
I have concentrated on the account of the business cycle given by Mises in Human Action, especially chapter 20 and Hayek's account is mainly taken from Prices and Production. I have supplemented these accounts with Roger Garrison's Time and Money and his Journal paper "Overconsumption and Forced Saving in the Mises-Hayek Theory of the Business Cycle». In addition, I have consulted Jesús Huerta De Soto's magisterial Money, Bank Credit and Economic Cycles, which I largely believe represents the perfecting of the theory and have also had the privilege of access to an in press paper written by Huerta de Soto's colleagues, Professors Miguel Alonso Neira, Philipp Bagus and Juan Ramón Rallo Julián, entitled «The First Global Financial Crisis of the $21^{\text {st }}$ Century: Origins and Proposals for Reform. An Austrian Approach».

I have decided not to spend as much time on other texts mainly representing earlier accounts of the theory, such as Mises' 1912 Theory of Money and Credit and Hayek's 1925 observations in «The Monetary Policy of the United States after the Recovery from the 1920 crisis» in a volume dedicated to his early papers, as I think that the main goal in this paper is to get clear on ABCT as most developed, though consideration of certain issues between Mises and Hayek are essential to this development.

We should note in passing that Mises account in Human Action is considerably later than Hayek's 1931 account in Prices and Production, a fact which surprises some who have come to believe that Hayek, as Mises' student, had the most complete and latest account of ABCT of the two. Certainly, Hayek continued to write on the theory long after Mises died, but it is a contention of this paper, that of the two, Mises has the more powerful account.

Finally, I should note that I intend this paper to be, above all, a propaedeutic to my Master's Thesis on «The Theory of the Impossibility Of Socialism», that is, I intend exactly to concentrate on development of the idea that the business cycle as a special case of problems arising from socialist institutions, as in the quotation from Huerta de Soto above and in line with his definition of socialism. My thesis will provide a much longer account of the epistemological errors of socialism than is possible here. 
II

\section{AN INITIAL ACCOUNT OF ABCT}

«...all major crises in the nineteenth and twentieth centuries stemmed from an excessive expansion of credit...» Nobel Laureate Maurice Allais (Allais [1993] p. 326).

The very first thing essential to understanding $\mathrm{ABCT}$ is to begin with an understanding of the role of savings. This is defined as "goods which are not consumed.»

The simplest example is that of the old standby, Robinson Crusoe. Quoting from Garrison:

... for some time (Crusoe) is content to sustain himself by catching fish with the aid of little or no fishing equipment. A greater output of fish is possible but only if Crusoe is willing to take time away from fishing in order to fasten a net and possibly a boat. Consumable output would have to fall while the production process is being enhanced. (Garrison [2004] p. 325).

In other words, Crusoe has to take time away from fishing in order to construct the capital equipment which will result in more fish later and he needs to save fish in order to sustain himself during this period; he cannot daily consume all he catches or he will starve before he gets his net and boat. (Strangely Garrison does not emphasise this point about saving, instead focusing on the fall in consumable output while the equipment is made and then on more output after it is made, as well as a longer production process subsequently. Crusoe cannot just stop eating while he is not fishing and would have had to save some fish for this period. Not only that, although the resulting process is more capital intensive later [more complex and involving more factors], it may well be a lot shorter in actual time for the same or increased number of fish caught, freeing up time for other activities such as building better shelter, a rescue signal bonfire etc... This is the opposite of what Garrison says).

We can see in Crusoe's case the 3 elements required for human survival above bare subsistence: Time, Savings and Production. Further, we can see that, in relation to Crusoe expanding his output 
and other activities involves a continuous process made possible by saving:

production is not a matter confined to the immediate moment, but a continuous process, and that production is fuelled by previous production... anything beyond a... precarious, hand to mouth existence requires savings. Savings buy time. (Rand [1984] p. 127).

The situation is not essentially different in a complex society which uses money. We can actually see a close link between savings, time and money illustrated in this further passage from Ayn Rand, who is here initially considering the case of a self sustaining farm:

On a self sustaining farm, savings consist mainly of stored grain and foodstuffs; but grain and foodstuffs are perishable... so you ate what could not be saved: your time range was limited. However, the time horizon can be pushed immeasurably further. You don't have to expand the storage of your food: you can trade your grains for some commodity which will keep longer and which you can trade for food if you need it. But which commodity?... -a tool of exchange-money.

... Money is not merely a tool of exchange: much more importantly, it is a tool of saving, which permits delayed consumption and buys time for future production. (Rand [1984] p. 127).

We should note in passing that as well as owing a lot to Carl Menger's account of the development of money (Menger [1892] pp. 239-55), Rand's account somewhat contradicts Mises's view that money is essentially most importantly a medium of exchange. I think the stronger case is Rand's, as the view that money "much more importantly» is a «tool of saving» fully brings out her earlier assertion that "production is a continuous process»-in other words, money is only useful to a saver on the basis that other people are continuing to produce. (The issue can be trivially resolved if we hold that money's role of a medium of exchange makes possible its efficacy as a tool of saving, but that does not emphasise the reliance on a continuous production structure, perhaps odd given the Austrian emphasis on time in economics.) 
I have not seen this point explicitly emphasised in the other literature we are discussing, though it was recognised by other writers such as Strigl (2000), and it is crucial; it is the interruption of the continuous process of production that makes inflation and the business cycle so dangerous. Again:

whether he wants to enlarge his production or to live on his savings (which he holds in the form of money)-in either case, he is counting on the fact that he will be able to exchange his money for the things he needs, when and as he needs them. This means that he is relying on a continuous process of production-which requires an uninterrupted supply of goods saved to fuel further and further production. This flow is «investment capital», the stock seed of industry. When a rich man lends money to others, what he lends them is the goods he has not consumed. (Rand [1984] p. 131)....money stands for existing but unconsumed goods. (Rand [1984] p. 133).

Similarly, «Credit means money i.e. unconsumed goods, loaned by one productive person... to another, to be repaid out of future production.» (Rand [1984] p. 130).

So far, we have considered the role of time, money and credit in the productive process, the latter the essential to any quality of existence above subsistence level. It is with respect to credit that the origins of the trade cycle arise-specifically bank credit. And it is at this point that we must understand what is called Fractional Reserve Banking, at least in outline. This is admittedly a vast topic in itself and excellent accounts have been given in Rothbard (2005 and 2008) and extremely comprehensively by Huerta de Soto (2008). Hence, we will concentrate on the essence of this issue in relation to our main topic, which is that banks create money without there being any concomitant production and saving of goods. We largely ignore until later complicating factors such as deposit insurance (e.g. The FDIC-Federal Deposit Insurance Corporation, which «insures» bank deposits against the failure of the insured institution.)

We have seen that with a commodity standard money, such as gold, the productive process is greatly augmented. However, it is the case that in each state in the world in modern times, the 
spontaneous adoption of such a commodity standard by free individuals has been usurped by Government monopolisation of the money supply via its extensive control and regulation of a notionally free and private banking system and its imposition of legal tender laws which, by force, require that only payments made in money defined as such by the government, is acceptable for any financial transaction.

Both the Government and the Banking system is incentivised to continually expand the money supply. The Government is incentivised to do so as such expansion is effectively a hidden tax on the pre-expansion money stock and by implication, wealth of society in the form of unconsumed goods. As Huerta de Soto observes-

... the decrease in purchasing power of money works in politicians favour, since income taxes are generally progressive. (Huerta de Soto [2008] p. 755). This is so called «fiscal drag».

But there is another incentive. The modern state seeks to continually expand its influence-in fact, this is often cited as the most firmly supported finding of the Public Choice school-and does so via increasing the size of the welfare state and control and regulation of the economy. It could well be added that modern democratic states are often warlike (see Gottfried in Denson [2009]), another activity which requires an expansion of controls and expenditure. (Hence the so called «Welfare/Warfare State», a phrase I believe coined by Murray Rothbard to describe the modern United States. See for example Salerno in Denson [2009]). On this Mises states:

One can say without exaggeration that inflation is an indispensible intellectual means of militarism. Without it, the repercussions of war would become obvious much more quickly... war-weariness would set in much earlier. (Mises [1998] p. 442).

(We should also mention that business, especially businesses involved in sectors of the economy that are investing in earlier stages of the production process on the back of bank credit, are 
very keen to see an existing inflation kept going. As we shall see, this is because their investment is in fact malinvestment and will be revealed to be so if the inflation is curtailed.)

These projects of the government are expensive and typically require what is called deficit financing to pay for-that is, expenditures in excess of tax receipts-as if the full cost of the projects was explicitly borne by taxpayers, they would very likely utterly reject the legitimacy of the government in power. This means the state develops debts and hence it is in its interests to see the real value of those debts fall: it pursues a policy of inflation which erodes the real value of the debt, often at the expense of creditors, but much more so at the expense of all other members of society who hold any monetary wealth. As we shall see, the burden falls on every member of society when it is remembered that the ultimate result of such inflation is the disruption of the productive process on which all depend.

The government can inflate directly, through the immediate creation of money by the central bank (really a branch of government] usually used to buy government debt, or by allowing the process to occur through the banking system. We shall discuss this further when considering directly Mises's account.

The banks, on the other hand, in what Huerta de Soto describes, in several places, as a «symbiotic relationship with the state» (e.g. throughout Huerta de Soto [2008]) have the simpler incentive that the process of inflationary credit expansion we have described gives them access to an immense amount of very low cost capital which in turn generates huge profits. Nevertheless, as Nassim Taleb has pointed out more than once, the banking industry as a whole has never made any net money in its history, as the losses sustained during crises wipe out the accumulated profits of boom periods. (For example, Taleb [2007] p. 43). Only Government privilege and bail outs allow this industry to persist and indeed the Government must ensure this, as the loss of bank deposits in a collapse would not encourage the compliant population it requires for its continued existence.

We shall now turn to the actual mechanism of inflation which must be briefly described, though is extensively so in Huerta de Soto (2008), chapters 4 and 5 . We should note the vital point first 
that inflation is defined as an increase in the money supply. This is the proper understanding of the phenomenon which gives us a grasp on its identity and causes. Inflation is not, as per official government definitions, some sort of change in an arbitrarily constructed price index. Changes in the prices of consumer goods is a common effect of inflation, but not inflation itself. I believe this confusion is deliberately fostered and pernicious-for cui bono? As we shall see, the government via its symbiotic relationship with a privileged banking system is the cause of inflation, a fact politicians will want to distract attention from. Hence, by focusing on an effect of inflation, the cause is left mysterious and can readily be blamed on greedy businessmen or capitalism itself.

Throughout their history, banks have discovered that depositors usually do not require their funds returned all at the same time. As a result the temptation arises to use much of the funds deposited with them to make loans to other individuals and businesses, as Huerta de Soto notes and argues at length, «in violation of traditional legal principles.» (Huerta de Soto [2008] chapter one). The interest accruing to such loans is income to the bank, some of which they pay to the original depositors, itself a sign, as Huerta de Soto argues, that something is clearly amiss: money itself will not earn interest and in fact the depositor should pay a fee, though typically banks charge this as well! The banks therefore assume a central dominant role in the economy and «earn» the spread between interest received and paid.

In fact, banks only keep a fraction of deposits on hand and have only the capacity to pay out a tiny number of their customers at one time-typically this fraction (giving rise to the term fractional reserve) is less than $10 \%$ of funds initially deposited with them. Having received a deposit, therefore of say $\$ 1000$, the bank has the capacity (via its legal privilege from the state) to make loans of up to, say, $\$ 10,000$, depending on reserve ratios. This $\$ 10,000$ in turn will probably find its way into bank accounts in either the same or different banks and will in turn generate a multiple of further credit expansion. We are here looking at only the simplest, broad outline. Rothbard (2004 and 2008) has shown why the banks need to cartellise in order to make sure that local crises 
do not erupt such as one bank being unable to honour request for redemption of its notes by another, and Rothbard also goes on to explain why the entire system requires a lender of last resort (the central bank) to keep the whole system going. Crisis erupts in fact when the banks simultaneously find that the value of the loans they have made is impaired (they are investment errors) and when the general public begins to lose confidence in the system. Hence, the central bank exists as a means of «injecting liquidity» (effectively printing money) to shore up banks reserves when they are diminished by losses and withdrawals. The very fact that the system requires such "confidence» is a key to the understanding that there is no real economic basis for much of the economic activity that the banks stimulate via their loans. If there was such a real basis, it would not matter if people had confidence in it or not.

We say that the banks are privileged as it is only by government degree that they can continue in business at all, in fact when they are technically insolvent, and are almost sure to be rescued during their self-induced crises. No other business enjoys such graces.

In turn, the Government manipulates the entire process via, on top of immense and labyrinthine banking regulations, control of the main interest rates (those charged by the central bank to the commercial banks for loans to them during, for example, the clearing process implied in the account above, where banks extinguish imbalances in amounts of each other's notes due each other) and by the central bank buying assets (usually already issued bonds) thereby increasing, out of thin air, the money supply which finds its way into banking deposits and allows further expansion as a multiple of such «base money» as it is called.

\section{The normal functioning of the relevant markets}

We shall now consider how money/loan markets would operate normally absent inflationary credit expansion, before proceeding in the next section to look at the results of the distortions caused by credit expansion. Our account borrows heavily and is based upon Roger Garrison's work (Garrison [2001 and 2004]) and in 
particular his innovative diagramming techniques. These are based on the commonly used PPF concept, or production possibilities frontier (the maximum output of an economy given certain levels of consumption and investment displayed graphically), and are used illustratively. In Huerta de Soto's words, such use of the PPF is

merely using a metaphor to enable... the neo-classical tradition to understand... without forgetting that this curve does not exist, as its points are not given (they constantly vary) and can never be known. (Huerta de Soto [2009] p. 323 FN. 17).

Garrison interlinks three diagrams to illustrate both the normal functioning of a loan market and the distorted operation. Two of the diagrams are standard supply and demand curves, one of which illustrates sustainable combinations of consumption and investment in relation to the production possibilities frontier, and the other, the supply and demand for loanable funds. The third is a "Hayekian Triangle» which by means of an upwardly right sloping right angled triangle, illustrates the discrete stages of the production process (i.e. in time) along the horizontal access and consumable output along the vertical access. The slope of the hypotenuse represents the imputed rate of return between stages in line with imputation theory, which describes a uniform rate of return throughout the parts of the production process [eg as presented in Rothbard (1993) pp. 387-98, and Huerta de Soto (2008) pp. 291-297, (Figures 1 and 2)].

The solid points in the upper right diagram represent a fully employed economy with a market clearing rate of interest-this means that the amount of money saved is equal to that invested. An increase in saving therefore allows an increase in investment and does so by curtailing consumption. Initially, the economy would move clockwise along the PPF (point A to B), itself defined as the maximum level of sustainable output the economy is capable of given certain levels of consumption and investment. Subsequently, because of a deepened capital structure, the PPF will move rightwards reflecting increased productive potential in exactly the same way as we saw happen with Crusoe in section 2.0 . 
FIGURE 1

\section{A HAYEKIAN TRIANGLE}

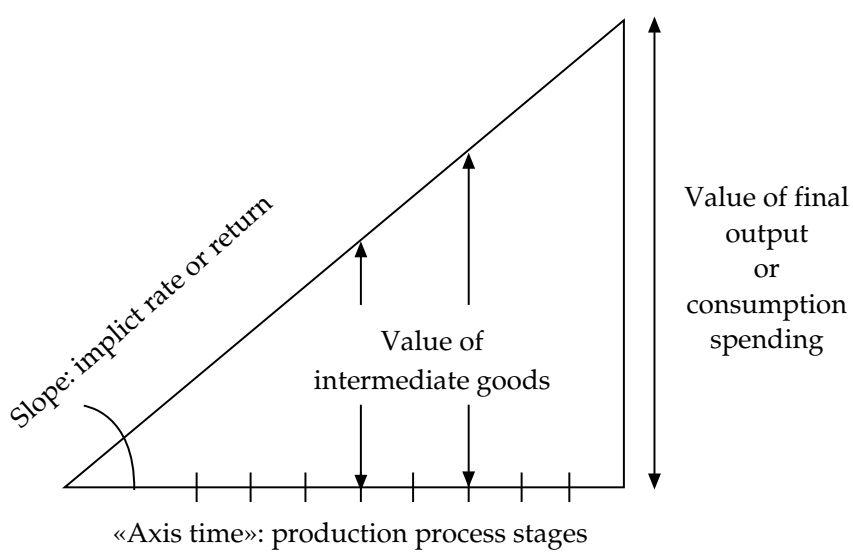

Source: Alonso, Bagus and Rallo (in press 2012).

FIGURE 2

GROWTH BASED ON THE PRIOR ACCUMULATION OF SAVINGS: A DECREASE IN THE INTERTEMPORAL DISCOUNT RATE

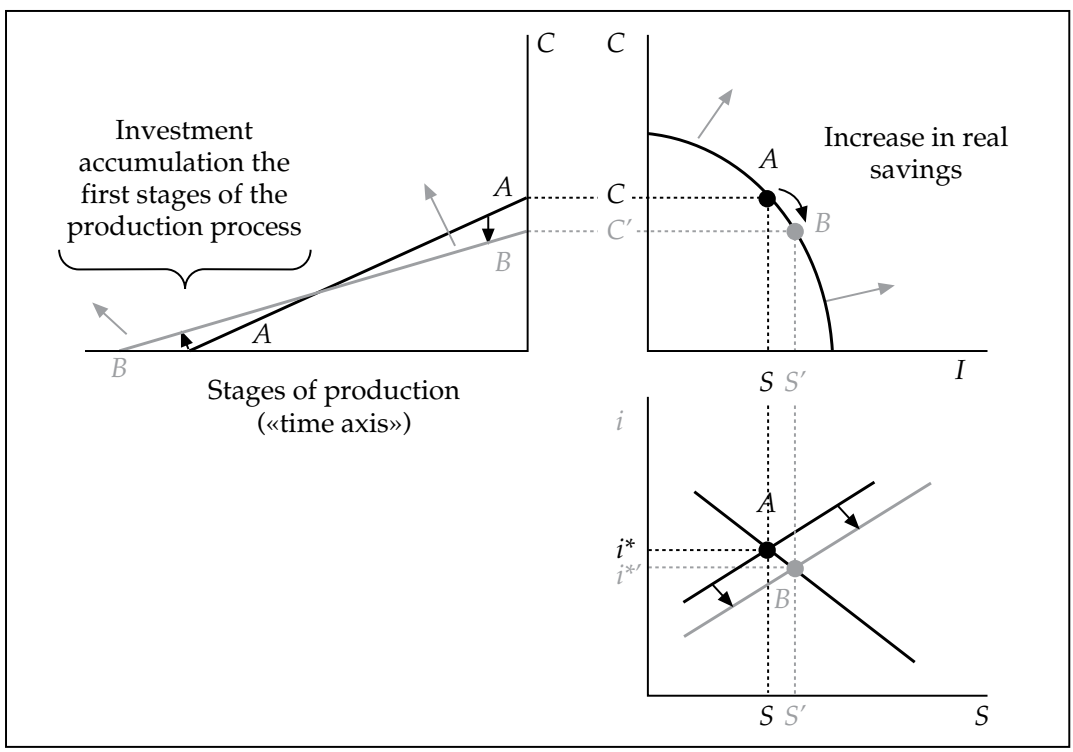

Source: Garrison (2001) p. 62. 
Below this diagram, we see the demand for loanable funds in the economy reflected on a further diagram showing the level of savings and investment at certain rates of interest. Again, we see the filled in spot represents the market clearing level of interest such that savings and investment are equal. The movement arrows indicate that because savings have increased, all else being interest rates can fall due to increased supply and entrepreneurs can raise capital for more investment projects more cheaply, particularly in the earlier stages of the production process or in adding stages, stimulating this activity- a movement from point $A$ to point $B$.

Finally, the Hayekian triangle shows the stages of production against consumable output as we mentioned. We can see that the effect of the increased savings is that 1) consumption falls, in fact this is the sine qua non definitional constitutive requirement of saving, and 2) the production structure lengthens. However, subsequently (lighter arrows) a greater consumable output will be the result.

It is of primary importance to realise that such a savings based expansion is sustainable-it does not lead to any sudden sharp contraction or bust. In section 3.5 we shall contrast savings based expansion with credit inflation induced growth in terms of specific microeconomic phenomena which have been delineated by Huerta de Soto (2008, pp. 397-399 and pp. 363-384).

I would like to mention again that I am uncomfortable with the idea that such savings must necessarily permanently lengthen the production shortage, as is shown in the Hayekian triangle and as is claimed in much of the literature. I think this is not logically necessitated. Technological progress and capital accumulation may well have the effect of shortening the production process in the medium term, as we eventually saw with Crusoe. This is despite the fact that progress normally entails at least a lengthening in the number and complexity of stagesfor I do not see why it should be logically impossible for progress to occur by finding ways to eliminate stages. Certainly, extra time must be funded by savings initially, but once new capital goods and production structures are in place, even allowing for depreciation and maintenance, overall the same or 
greater levels of output may be achieved in a much shorter period.

For example, it takes Crusoe 5 hours to catch a fish by hand. It takes him half an hour to catch one with his newly fashioned rod. It takes him a week to make the rod and it lasts a year. His production structure initially is 5 hours from initiating his investment of labour, through to consumption. He takes a week of labour and gets a rod, financed by savings. The production structure lengthens. This depreciates at the rate of $1 / 52^{\text {nd }}$ per week and maintenance therefore costs the same, or $1 / 52^{\text {nd }}$ of a week each week. But now the production structure has shortened to 30 mins labour plus $1 / 52^{\text {nd }}$ of a week maintenance from 5 hours, from beginning to consumption.

It is in making the amenities of life more immediately available that economic progress consists. (Mises [1998] p. 467). Emphasis mine.

\section{The distortions caused by inflationary credit expansion}

Now let us consider the following amended version of the diagrams.

Here the key diagram is the lower one. This shows that credit expansion (represented by the blue line) appears to the market exactly as if savings had increased, i.e. that more resources are available for investment than is the case and that this is reflected in a lower interest rate. The credit funds are available to entrepreneurs who invest it into the early stages of production. Initially, this allows the economy to exceed the PPF, but unsustainably so, eventually falling back below the PPF (upper right diagram) into depression. The real resources signalled by the credit expansion do not exist, so the entrepreneurial investment is in error (malinvestment), though while the money supply continues to expand, this process can be kept going and the error not apparent for some time. (We will examine the proximate causes that bring this process to an abrupt end below.)

As Alonso, Bagus and Rallo note: 
Throughout this process, instead of having a real transfer of resources from savers to investors (entrepreneurs), they compete for them in a tug of war. (Alonso, Bagus and Rallo [in press 2012]).

I think the basic ideas in the diagrams are clear, though I have pointedly not discussed some of the terms appearing, such as forced savings, overinvestment and overconsumption as I will examine these ideas in later sections.

\section{FIGURE 3}

UNSUSTAINABLE GROWTH: THE AUSTRIAN BUSINESS CYCLE

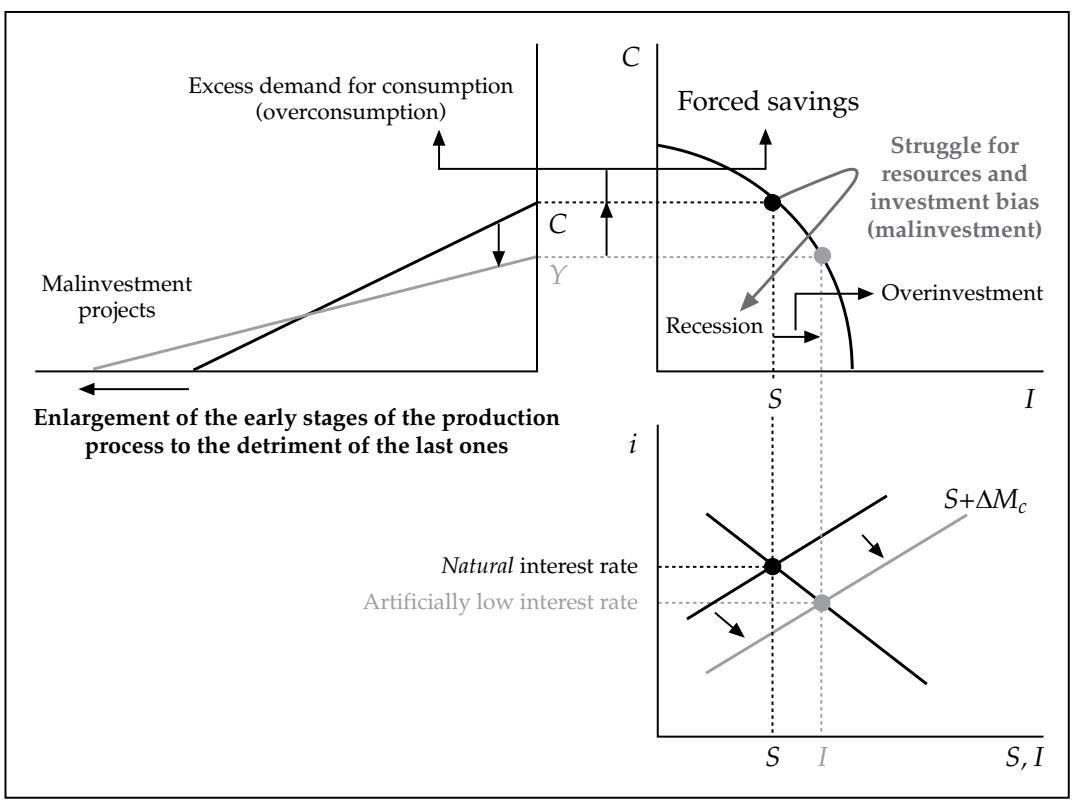

Source: Garrison (2001) p. 69.

The hope springs eternal, and indeed is the essence of Keynesianism, that inflationary credit expansion can somehow spark real expansion by motivating an increased development of resources and also via the mechanism of «forced saving» (see below). This depends on the ex post facto logically necessary truth that all invested resources have been saved-so that investment 
could be envisaged as leading saving (rather than vice versa). However, this overlooks the fact that resources can be invested foolishly (malinvestment) so that the completion of such investments relies on resources which don't exist and that the savings are goods, not inflated credit. (See Huerta de Soto [2008], pp. 548549).

A final point which we should emphasise in this section is that the popularity of inflation as a government policy comes from both greed and fear. Greed for the false prosperity that inflation seems to bring and, as we mentioned earlier, fear, especially within the business community, as to what will happen if the inflation is stopped. For continuing, indeed accelerating, inflation is required to keep malinvested business projects afloat. If the credit increase is stopped, malinvestment is revealed as it, by definition, has no proper business or demand based foundation-a fact obscured by its only apparent profitability while credit expands.

Indeed, a belief that further inflation is the cure for a slump is very widespread as it allows such businesses to continue at least for a while but also lowers the level of real wages, going some way to alleviating unemployment, but all at the cost of an even greater slump later.

In the last sections we have seen a basic outline of the ABCT, actually as materially developed by Roger Garrison, though in such a way as to visually present and therefore simplify the underlying mechanisms. In the next chapter, we shall look at Mises and Hayek's contributions more exegetically.

However, first, there are some basic points that it is necessary to address in this chapter-namely, why is this process an example of socialism as defined by Huerta de Soto? Why do entrepreneurs repeatedly fall into the trap of malinvestment, set by credit expansion? And finally, are there any alternative accounts of the process of boom and bust which might provide a plausible alternative explanation? 


\section{ABCT as an example of the necessity of economic miscalculation under socialism}

It is worth repeating Huerta de Soto's definition of socialism-

Socialism is any system of institutional aggression on the free exercise of human action or entrepreneurship. (Huerta de Soto [2010] p. 4).

We can readily see such aggressive interference in the actions of both the state and the state-privileged banking sector, in that the interest rate on loans is altered by such interference setting in train the process and that the funds necessary for malinvestment are provided, actually created ex nihilo, by the same parties.

These actions are types of aggressive interference as they can only be achieved by force-an informed and free society would likely not tolerate them. For example, the natural rate of interest is that arrived at by individuals engaged in voluntary transactions in conditions of sound money, itself selected by the market. In inflation, the interest rate is manipulated downwards by forceful increase of the money supply, expropriating all other holders of money ex ante, and on the basis of a type of money imposed upon the market and not freely selected by it. Force is also used against the creditors of the banks in that these institutions are privileged to continue in business when they are always technically insolvent and are bailed out, using the resources of the rest of society, when crisis erupts.

It is worthwhile to note here that not only does the system described fit Huerta de Soto's definition perfectly, it of course also suffers, or more properly inflicts, exactly the consequences predicted by von Mises in numerous writings on the «Socialist Calculation Debate». For it was established by von Mises that it is impossible for a socialist society to exist successfully as it does not have the free price system based on private property necessary for economic calculation.

The interest rate, as we have seen above, is a price (the price of credit) which emerges to balance exactly the level of savings and investment under conditions of free exchange and given the intertemporal preferences (how much will be save as against 
consumed) of members of society and the actual level of resources of society. Mises ([1998] p. 523) states that an interest rate is not a price as such but «a ratio of commodity prices». It nevertheless serves the function of price exactly and the distinction is obscure. All this vast amount of information, extending across many millions of individual circumstances, is made visible to investors via prices. This information, which is tacit, dynamically changing, subjective and dispersed, cannot be centralised (Huerta de Soto [2008] pp. 650-664 and [2005] in entirety). In fact, it will not be generated at all if the incentives to do so are removed by coercion.

But when the price system is forcibly interfered with, this information is lost and investments are made out of kilter with individual's intertemporal preferences and the actual level of resources in society. Entrepreneurs in fact receive false signals under conditions of interference and massive mistakes follow inevitably.

This was exactly the problem faced by communist regimes and in fact, as Huerta de Soto notices, the central bank dominated and orchestrated system looks conspicuously Soviet!

The organisation of the banking system is much closer to a socialist economy than to a market economy. (Huerta de Soto [2008] p. 652).

In fact, the banking system is basically structured as a command economy.

Like Gosplan, ... the planning agency of the... Soviet Union, the central bank is obliged to make an unceasing effort to collect an extremely vast quantity of statistical information on the banking business...» which simply cannot include «...the qualitative data the central bank would need to harmlessly intervene in banking affairs». (Huerta de Soto [2008] p. 656). 


\section{Why do entrepreneurs not learn to realise that a booming investment market is generating false signals and to avoid investing?}

We have seen that the phenomenon we are studying is recurrent, and in fact exhibits largely the same structure again and again. Huerta de Soto gives detail on a large number of examples from 1819 to the present day (Huerta de Soto [2008] p. 482 ff). Surely entrepreneurs can learn to resist the siren calls of cheap money? Indeed, this is precisely the criticism of ABCT of the so called «rational expectations» school.

In Human Action, chapter XX.8, Mises indeed discusses what he calls «the only objection ever raised against the circulation credit theory». (Mises [1998] p. 570). The most common modern objection however is precisely that the Misesian theory of the trade cycle assumes business people are incapable of learningironically the same objection Mises later directs against other theories of the cycle (Mises [1998] p. 581). In particular, rational expectations theorists demand to know:

Why doesn't the business community realise the gross rate of interest is false? Why do entrepreneurs mechanically plug in just that interest rate to compute profitability, rather than studying monetary policy and adjusting their calculations. (Murphy [2008] p. 218).

This objection misses the point completely. For in order to adjust the given rate of interest to the natural rate, entrepreneurs need the market to tell them what it is. In addition, conditions will be so changed this becomes logically unknowable-in a market suffering such massive interference the pattern of industry which would exist in a free market is altered, so in effect there can be no natural rate to work out. This information is simply not generated.

Further, entrepreneurs face what might be called a prisoner's dilemma type situation. They will see their competitors greatly expand profitability and capital base and, if they do not follow them into the booming market, face greatly diminishing their competitive position, or even going out of business altogether. 
The incentives to partake in the boom are enormous-I have personally heard about a senior Mises Institute Fellow who told a lecture group that in the recent boom, although he was well aware of what was going on, he could not resist making investments for the fund he controlled, as substantial gains repeatedly resulted. It would have been psychologically impossible to see his relative position massively diminished.

It is also quite possible that part of the boom conditions are actually real-perhaps driven by a new generation of technology breakthroughs. The point is that businessmen just can't tell under conditions of such interference, though at least study of money supply statistics will give a strong clue that a false expansion may be underway, but not at all when it will end. Hence, many who believe they can liquidate in time will be inevitably caught

... printing new pieces of paper does not create additional capital goods. If entrepreneurs attempt to lengthen the structure of production even though people have not freed up resources by cutting back on their consumption, at least some of the entrepreneurs will have to abandon their projects before completion. (Murphy [2008] p. 210).

The last clause indicates a conspicuous feature of the bust period-massive failures in the production industries furthest from consumption .

We can also see here a further incentive for the state to inflate in the first place, in that the artificial boom conditions are extremely popular with voters while politicians do all they can to disassociate themselves from the bust.

\section{Alternative views of the business cycle}

Many alternative views on the causes and treatment of the business cycle have been advanced. In this section, it will be possible only to mention three in outline-non-monetary explanations, Keynesian explanations and neo-classical/monetarist theories. 
The first of these, as exemplified by Schumpeter, are those who wish to explain the business cycle in terms unrelated to the money supply. In Schumpeter's case, this was by a focus on the effects on the introduction of new technologies and the subsequent competing away of its advantages.

However, Mises decisively rejects all such attempts:

... every nonmonetary explanation of the cycle is bound to admit that an increase in the quantity of money... is an indispensible condition of the emergence of the boom. It is obvious that a general tendency of prices to rise which is not caused by a general drop in production and in the supply of commodities offered for sale, cannot appear if the supply of money... has not increased. (Mises [1998] p. 579).

We will remember the critical phenomenon to be explained is the prevalence of severe forecasting errors in general across many sectors-only "the driving force of money» (Mises [1998] p. 578) can explain this.

We now turn to Keynesian and Neo-Keynesian explanations. Keynes view is that there is an inherent instability in the capitalist process, driven by «animal spirits» or a propensity to take risks in pursuit of gains. The risk taking behaviour of the investment banks in the recent crisis is under scrutiny currently, and such thinking undergirds a great deal of the deliberations of modern policy makers. A specific instance of this is in the thinking of Hyman Minsky, discussed in Alonso, Bagus and Rallo (in press 2012).

The key mechanism that pushes the economy towards these recessionary scenarios, is the progressive accumulation of debt by individuals and firms during the expansionary phases of the cycle. (Alonso, Bagus and Rallo [in press 2012]).

However, as these authors point out

... the heart of credit is not money as such, but the pool of real savings... The prior accumulation of real savings... is the basis of sustainable economic growth. Therefore, an expansion of the 
supply of loanable funds sustained by an earlier generation of real savings cannot damage the economy...

Minsky lacks «a theory of capital» which allows him to analyse the differential impact of credit expansion on the stages of the production process. (Alonso, Bagus and Rallo [in press 2012].)

I think Alonso et al.'s remarks are decisive yet it cannot be over-emphasised how the risk taking, animal spirits explanations of Keynes and Minsky are still widely believed to be a structural, necessary flaw in markets. As an example, Vince Cable, the most highly regarded economic thinker in the British Parliament and the Liberal-Democrat Shadow Chancellor states in his recent book

A generation ago, Hyman Minsky described the mechanisms by which financial markets regularly over-reach themselves, through excessive leverage... (Cable [2009] p. 7).

This is not to say that «excessive» risk taking is not an element in crisis. It is. However, it is not at all the essential element. In fact a key point is that investors do not know they are taking risks, but are simply responding to false signals of profitability. The banks funding them are creating these signals and taking risks themselves, but the point is that they are able to do this using the appropriated wealth of the rest of society. The essential is to prevent this appropriation through inflation so that whatever level of risk is adopted, it is born directly by the risk taker and not, through the inter-related fractional reserve banking system, by the whole of society.

A great deal more may be said concerning the (I believe wholly pernicious) influence of Keynes on economic thinking which we cannot present here. However, we shall return to Keynes in order to discuss an element emphasised by him-that is, the possibility that stimulation and government intervention may be necessary to restore the economy to the PPF, following a contraction to within this-i.e. to an economy which is at sub-potential levels of consumption and output.

Finally, in this section, we turn to neoclassical/monetarist thought. Again, a substantial exegesis is not possible but let us 
look at the essential aspects ignored by these schools which incidentally Huerta de Soto groups with the Keynesians:

... the differences between monetarists and Keynesians are... trivial and mostly apparent, since both groups apply very similar «macro-economic» methodologies in their analyses. (Huerta de Soto [2008] p. 530).

The essential aspects of this schools deficiency is in regard to their ignoring the factor of time in their thinking, their concept of capital and their mechanistic model of money relations.

We actually saw the difficulty of presenting time earlier in our examination of Garrison's supply and demand curve diagrams. Garrison could only present the picture at an instant and had to use shaded arrows to indicate a change which would occur later. Only the Hayekian triangle was able to present time as a series of stages of production. Similarly, the neoclassical school actually disregards time altogether in its analysis, presenting such equilibrium models as taking shape in an instant. That this is pernicious can be seen in conjunction with the mechanistic quantity theory of money, presented in the literature usually as the equation of exchange$\mathrm{MV}=\mathrm{PT}$, where $\mathrm{M}$ is the money stock, $\mathrm{V}$ is the "velocity of circulation», $\mathrm{P}$ is the general price level and $\mathrm{T}$ is the "aggregate» of all goods and services exchanged in a period.

Now, firstly, as Huerta de Soto states:

$\mathrm{T}$ is an absurd «aggregate» which calls for adding up heterogeneous quantities... the lack of homogeneity makes this an impossible sum. (Huerta de Soto [2008] pp. 531-2).

Huerta de Soto goes on to quote Mises on the equally absurd idea of the velocity of money, which is defined simply as the variable which is necessary to make the equation of exchange balance!

As regards the price level, $\mathrm{P}$, this is exactly where the Austrian insights are lost and underlines that the neo-classicals, like Minsky and the Keynesians, have a deficient or non-existent theory of capital. Hayek stated that 
his chief objection against (monetarist) theory is that, as what is called a «macro-theory», it pays attention only to the effects of the changes in the quantity of money on the general price level and not to the structure of relative prices... it tends to disregard... the most harmful effects of inflation: the misdirection of resources and... unemployment which... results. (Hayek quoted in Huerta de Soto [2008] p. 526).

In other words, monetarists assume that money is «neutral». On the contrary, Rothbard makes clear why it certainly is not:

creation of paper or bank money... confers a special privilege on some groups, at the expense of... producers and (money holders). The groups that benefit include the first issuers (the banks) and receivers of the new money, those who sell to them, and generally those whose selling prices rise because of the inflation before a rise in prices of the goods they have to buy. (Rothbard quoted in Sciabarra [2000] p. 296).

These are effects which take place over time and for a period seem to indicate that the areas of first receipt have become especially profitable and therefore attract resources into them-the money supply change therefore has a real effect on the distribution of resources to the benefit and detriment of different groups. Money is not neutral and markets cannot equilibriate instantly. In fact, even if there is an increased demand for money, this does not neutralise the economic dis-coordination caused by inflation:

... the supply of fiduciary media does not generally go into the pockets of... economic agents whose demand... may have increased, but reaches them after a long and sinuous process, passing previously through the pockets of many others... and distorting the whole productive structure during... transition.

(Credit is instead)... granted to entrepreneurs, who receive and entirely invest (it) without taking any account at all of the proportion at which the final holders... desire to consume and invest. (Huerta de Soto [2009] p. 154).

We see also in this connection the poor understanding of capital as this is analogously, not a neutral or homogenous pool, 
but is rather comprised of many different types capital goods which are mostly specific and non-convertible:

The basic mistake-if the substitution of a meaningless statement for the solution of a problem can be called a mistake-is the idea of capital as a fund which maintains itself automatically... (Hayek quoted in Huerta de Soto [2008] p. 520).

And Huerta de Soto directly:

Neo-classical theory tends to treat capital in general in this way: there is no good or bad capital investment: it's all just capital. (Huerta de Soto [2009] p. 272).

With these criticisms in mind we can quickly dispose of the usual strategy for explaining and remedying busts in the monetarist school, for example as exemplified by Friedman and Schwartz (1971). The core idea of this book is that the 1929 Wall Street Crash only became a depression because the US central bank (the Federal Reserve) allowed the money supply to contract by some $35 \%$. All that was required to restore economic growth was to increase the money supply, effectively to reflate -bank failures attending the contraction of course have the effect of deflation. This approach ignores, because of the poverty of its theoretical model of capital, the distortions caused by the earlier inflation which would be left in place and in fact exacerbated by such a policy. Indeed, that is exactly what we are seeing today in the Federal Reserve under Ben Bernanke. It is also unclear as to what any coherent general monetarist position is on the general causes of bust in the first place as they cannot cite, given their commitment to the homogenous capital theory and neutral money doctrine, the cause as a distorted pattern of investment and unsustainable consumption. It is also profoundly ironic that Monetarists, who advocate freedom of markets in nearly every other sector, demand a Soviet style command and control system with respect to money, exactly the sector which can do most harm to the economy as a whole.

Indeed, the monetarists entire position appears to rest upon the fallacy that an expansion in money is needed to serve industrial 
expansion. Hume ([1985] p. 286), Rothbard ([2005] p. 41) and Hayek (1984 [p. 97]) all show that once a commodity is accepted as money, there is no advantage whatsoever in changing the amount in circulation. E.g.

there is no basis in economic theory for the view that the quantity of money must be adjusted to changes in the economy if economic equilibrium is to be maintained... or disturbances are to be prevented. (Hayek [1984] p. 106).

In fact, Hayek's stated goal in writing Prices and Production was to show that

the cry for an elastic currency which expands or contracts with every fluctuation of demand is based on a serious error of reasoning. (Hayek [1935] introduction).

As Rothbard explains:

An increase in the money supply... only dilutes the effectiveness of each... (unit); on the other hand, a fall in the supply of money raises the power of each... (monetary unit). We come to the startling truth that it doesn't matter what the supply of money is. Any supply will do as well as any other supply. The... market will simply adjust. (Rothbard [2005] p. 41).

In conclusion, I think that even this brief outline indicates that the prevalent alternative schools of thought competing with the Austrian have very poor resources at hand to explain the boombust cycle, mainly a deficiency in their understanding of time, capital and the non-neutrality of money as well as the vital relation of real savings to sustainable economic expansion.

\section{The 2000 crisis in technology}

Before moving on, I would briefly like to mention the great surge in stock market values in the late 1990's, which was focused on the technology capital equipment sector and which quickly 
spread to many other areas of that industry. The money supply did grow quickly during the period but there was no conspicuous banking crisis at the boom's end-this appears to have been because most of the investment into technology was via equity issue, and not credit. However, it was the case that substantial loans were advanced to telecommunication equipment companies and many large investors were able to leverage their portfolios in investing into technology equity. Nevertheless, the year 2000 date change issue caused a very substantial upsurge in technology spending, via reduced spending elsewhere in the economy (i.e. not an inflationary expansion in this respect). Hence the boom was only partly driven by inflationary expansion and indeed the collapse of technology share prices was presaged by Federal Reserve tightening. However, I am not aware of an extant Austrian study of this period and hope to revisit this issue in the future. The relative lack of a full scale banking crisis at the period's end, compared at least to 2008, does not seem to fully fit with the Austrian account, though this is likely defeasible when real factors are taken into account. It is an interesting case because the $\mathrm{Y} 2 \mathrm{~K}$ date crisis represents a real factor which caused a market boom, in addition to credit expansion.

\section{III MISES AND HAYEK}

We shall now consider the essential elements of Mises and Hayek's contribution to ABCT, having been put in a position to fully appreciate this in the light of our earlier review of the theory in more developed form. (eg. the treatments made by Huerta de Soto and Garrison).

In summary, the essential difference between Mises and Hayek is that Hayek focuses only on misallocated capital, while Mises includes as well a focus on overconsumption during the boom. The difference stems from the respective applications of the loanable funds model and the use of the doctrine of forced savings, which means different things to each. Our analysis shall proceed by focus on key concepts and is greatly assisted by 
Garrison (2004). We shall also follow Garrison in looking at the concept, not considered by Hayek, and rejected by Mises, of «over-investment».

\section{Mises}

The central problem of the business cycle is repeatedly summarised by Mises with variations of the phrase "malinvestment and overconsumption». (See Garrison [2004] p. 327). The malinvestment phase is recognised and emphasised by Hayek and has been analysed above in detail. As we shall see, he refers to malinvestment as «forced savings».

However, uniquely, Mises also indicates that there is an increase in consumption in the boom period. As Garrison notes, this is consistent with the loanable funds theory we have already considered and illustrated:

Saving is augmented by credit expansion. Nonetheless the rate of interest... fall(s)... and business... undertake[s] greater investments and would tend to allocate the credit financed resources to the early stages of production. But since saving... has not changed... the lower rate of interest means that the amount saved actually decreases. (Garrison [2004] pp. 327-328).

In other words, savers are incentivised to save less and the overall savings/investment ratio is diminished. As well as this relative effect, absolute levels of consumption will also rise with increased apparent wages and factor incomes. Continuing:

Only in the extreme and unlikely case of a perfectly inelastic supply of loan-able funds would there be no decrease in saving... credit expansion causes the volume of saving to decrease-which is to say it causes consumption to increase. This increase in consumption associated with a policy induced decrease in the rate of interest is justifiably labelled by Mises as «overconsumption». Workers and other factor owners receiving increased incomes as a result of credit expansion will be induced to consume more than is implied by their pre-expansion inter-temporal choices. (Garrison [2004] p. 328). 
Mises mentions the Hayekian phrase «forced savings» in two senses, both of which are distinct from Hayek's meaning. Firstly, in Human Action XX.5 he draws attention to the phenomenon where:

Many writers focus on a certain possibility where an infusion of new money redistributes income from a segment of the population who do not save much into the hands of those who have a higher propensity to save. These writers thus claim that inflating the money supply can have the beneficial consequence of additional real savings and capital accumulation. (Mises [1998] chap. XX.5).

It is acknowledged that this is a possibility, but certainly not a necessity or even a likelihood. However, it also ignores the overwhelming likelihood of capital consumption as people are fooled by rising prices into thinking they are wealthier than they are and raise their consumption inappropriately. Mises comments-

It is very questionable whether forced savings in this sense can achieve more than to counterbalance part of the capital consumption generated during the boom. (Mises [1998] p. 575).

As Robert Murphy notes:

This situation can persist temporarily, because resources can be devoted to the production of present goods rather than to maintaining the stock of capital goods. The situation is analogous to a farmer killing his last chickens... for a feast, because he mistakenly believes there were dozens more in the coop. (Murphy [2008] p. 209).

In fact, Hayek emphasises this very point:

... when incomes are increased by investment, the share of the additional income spent on consumer's goods during every period of time should be larger than the proportion by which the new investment adds to the output of consumer's goods during the same period... there is... no reason to expect that more than a fraction of the new income (created by credit expansion), and certainly not as much as has been newly invested, will be saved, because this would mean that practically all the income earned from the new investment would have to be saved. (Hayek [1976] p. 378). 
Mises goes on to note that if it were not for the continual injections of new money into the loan market, the boom would come to an abrupt end. Entrepreneurs would realise their plans had been overly ambitious. However, as more and more new money is created (what Mises calls «Fiduciary Media») the dislocations grow ever greater and crisis is bound to come. We shall look at the exact causes of such an event later, but for now this integrates with the second use of the term "forced saving» in Mises. This refers to an increase in saving near the end of the boom caused by rapidly appreciating prices of consumer goods. This effect may be exacerbated by an increase in interest rates used by the authorities to try to counteract CPI increases.

We should note that Mises emphasises the importance of new money being introduced via the loan market, particularly as these are in a form of deferred payment. (Mises [1998] chapters XX.3 and XX.4). Inflation per se, as when the government simply sells bonds to the central bank, does not, according to Mises, set off the business cycle. (Mises [1998] chapter XX.7) The reason that the increase in the supply of credit is exactly offset by the governments demand though prices will ripple up from the overall supply of new money in the economy.

\section{Hayek}

Hayek uses the term «forced saving» differently. «Forced»emphasises the contrast with voluntary saving. The policy induced lowering of the interest rate causes the economy to react as if additional savings had been made without their having been so. However as recognised by Garrison (2004) the term is misleading. What Hayek is actually talking about is a pattern of investment which is at odds with savings preferences-this is precisely Mises's «malinvestment».

However, Hayek ignores «overconsumption» entirely. Garrison (2004, p. 333) notes:

For Hayek overconsumption seems to be ruled out by the very concept of forced saving: «This phenomenon, we are to understand, 
consists of an increase in capital creation at the expense of consumption...»

Also «...society as a whole will have to put up with an involuntary reduction of consumption.» (Hayek [1935, 1966] p. 88).

Yet certain Austrians such as Fritz Machlup and Richard Strigl have demonstrated how Hayek's own triangle device can demonstrate the straightforward possibility of both over consumption and malinvestment occurring simultaneously:

The additional credit causes an increased demand for consumer goods without a substantial delay. The output of consumer goods is elastic, indeed, and simultaneous expansion of production in the construction goods industry and the consumption goods industry takes place. We see at the same time symptoms of a lengthened production period and a swelling at both ends of the production structure at the expense of some middle parts of the stage system. (Machlup quoted in Garrison [2004] p. 332).

Garrison summarises the differences between Mises and Hayek, thus:

In summary terms, we can say that Hayek sees the boom bust cycle as forced saving, which is eventually countered by intensified consumption demand. Mises sees the boom as malinvestment which is immediately compounded by overconsumption. (Garrison [2004] p. 334).

\section{Overconsumption}

I think that Mises very much has the best of this debate. This is firstly because, as Garrison notes, it is not at all clear why Hayek ruled out overconsumption as a possibility (except in a relative sense as the boom falters) when his own framework accommodates it easily. Indeed, also noted, is the fact that high absolute levels of consumption are exactly what partly constitute most boom conditions.

John Hicks (1967) criticised Hayek for not showing why recipients of credit inflated incomes would not spend this money 
on consumption almost immediately. Hicks believed that without such a lag, "counter-movements» of resources would take place almost immediately, ending the boom very early. That is on the assumption that consumption industries and earlier stages can only operate at peak output at each other's expense. However, given an overall level of belief in a false prosperity, Garrison shows why this is not so:

Both Capital and labour can be employed more intensely than on a sustainable basis. Routine maintenance of machinery can be postponed, and the machinery kept running more hours per day or more days a week than usual. A greater proportion of the population can be drawn into the labour force, some workers can work over-time, and others can postpone retirement. These considerations allow for the production of both investment and consumption goods to increase simultaneously but, of course, not on a sustainable basis. (Garrison [2004] p. 336).

The boom in fact ends when Hick's assumption is realised after the depreciation of machinery and the exhaustion of labour causes resource shortages, as these cannot be sustainably provided for all stages of the production structure:

... Entrepreneurs relying on new loans may continue to lengthen the production structure without provoking the familiar reversion effects until the moment one of the complementary factors of production becomes scarce. (Huerta de Soto [2008] p. 553). My emphasis.

Hence, it is to be expected that both consumption and investment will exceed sustainable levels for some time before forces such as irreparable depreciation and exhaustion of labour become noticeable, triggering the crisis and evoking the sudden competition for scarce resources between different stages of the production structure that Hicks implies. Thus, Hayek's account is defective in this respect and Mises is correct that it is to be expected that malinvestment and overconsumption occur together. 


\section{Overinvestment}

The above quotation from Garrison [(2004) p. 336] is also useful in assessing Mises' contention that there is no such thing as overinvestment, rather only malinvestment. Malinvestment can be understood as an inappropriate emphasis on parts of the production structure at the expense of other parts. Overinvestment may be understood as the over-utilisation of the entire production structure. This is not in contradiction to Say's Law as it is understood to be a temporary phenomenon, which does not produce a glut of overproduction (as Say's Law denies is possible), but on the contrary conceals actual consumption of capital.

Mises denies there is ever over-investment:

The whole entrepreneurial class is, as it were, in the position of a master builder whose task is to erect a building out of a limited supply of building materials. If this man overestimates the quantity of the available supply, he drafts a plan for the execution of which the means at his disposal are not sufficient. He over-sizes the ground-work and the foundations and only discovers later... that he lacks the material needed for the completion of the building. It is obvious our master-builder's fault was not overinvestment, but an inappropriate employment of the means at his disposal. (Mises [1998] p. 557).

As Garrison states this

does not demonstrate the absence of overinvestment any more than it demonstrates the absence of overconsumption. (Garrison [2004] p. 346), which elsewhere Mises insists upon.

Hence, I think Garrison has actually shown that a problem of overinvestment is indeed a component in the boom-bust cycle.

\section{The proximate causes of the bust}

Garrison believes that the most significant difference between Hayek and Mises lies in Hayek taking an increase in consumption to be a reversal of the market process set in motion by credit 
expansion (Garrison [2004] p. 343). We have already seen why this is so, in that there appears to be an implicit assumption in Hayek (drawn out by John Hicks) that the consumer, consumer goods and capital goods industries must all compete in the short term for resources and can only expand at each other's expense, so to speak. That is, Hayek seems to envision movement along the PPF as opposed to seeing that the economy can temporarily move beyond the PPF. We have seen that, in the short term, this is not so. We also saw that a proximate cause of bust was an interruption in the production process occasioned by the eventual shortages caused by what we have described as overinvestment.

However, a very comprehensive taxonomy of micro-economic forces which have necessitate the bust phase and which are necessarily set in motion by the inflation of credit-or more accurately are actually constitutive of it- is given by Huerta de Soto [(2008) pp. 363-383]. The first 5 are transitional phases with the sixth the crisis proper. These are:

1. The rise in the price of the original means of production caused by the fact that no resources are released by savings to supply demand at these early stages and a lower level of interest rate increasing, often dramatically, the present value of projects at this stage, which are by nature longer term and therefore more interest rate sensitive. This diverts resources and labour to these stages and many new long term projects are commenced.

2. The subsequent relative rise in the prices of consumer goods (against early stage capital goods), caused by increased wages bidding these up from those sectors which receive the new money and a relative constriction of resources in supplying these as investment accrues into the earlier stages.

3. The substantial relative increase in the accounting profits of the companies from the stages closest to final consumption, as a result of 2 and which encourages production now into these stages.

4. The Ricardo effect, as labour is substituted for machinery in the consumer goods stages: 
the more than proportional growth in the price of consumer goods with respect to the rise in factor incomes drives this income, particularly wages, downwards in real terms, providing entrepreneurs with a powerful incentive to substitute labour for machinery... (Huerta de Soto [2008] p. 369).

5. The increase in the loan rate of interest. Rates exceed even precredit-expansion levels.

This rise occurs... when the pace of credit expansion unbacked by real saving stops accelerating. (Huerta de Soto [2008] p. 371).

This represents an «inflation component» in interest rates and the fact that entrepreneurs at the earlier stages must now compete more vigorously for funds to try to complete their projects, as resources are competed for by those stages closer to consumption. Mises points out that the boom ends when earlier stage entrepreneurs experience financing difficulties, as they are most vulnerable to interest rate changes. In addition, ceteris paribus, interest rates will seek to return upwards to their pre-expansion level once downward pressure is eased.

6. The appearance of accounting losses in companies operating in the stages relatively more distant from consumption-the inevitable advent of the crisis.

This gives rise to now growing unemployment and a banking crisis as loans fail to perform. Early stage entrepreneurs at the early stages now cannot bid for resources as the level of input costs now renders their projects unprofitable at best, and often impossible.

The crisis can be delayed by preventing 5 . by again accelerating the creation of new money. However, this will only be at the cost of creating even greater economic dislocation, as resources are misallocated for longer and capital is consumed more fully. The possible final outcome for such a policy is what Mises terrifyingly calls «The Crack Up Boom» of hyper-inflation. (However, by attempting to avoid the consequences of bust the authorities can worsen the duration of the depression, as appears to have occurred in Japan, or indeed tip into the sudden deflation associated in the form of a final banking collapse-the latter is a higher risk the more 
re-inflation attempts continue. Philipp Bagus has written extensively on prolonged periods of deflation as a possible consequence of the prior credit inflation, at those times when the state continues to try to prop up the tottering false productive structure, spinning its gears so to speak, again as exemplified by Japan today. We do not have space to pursue this here. In the end, as Huerta de Soto noted on page 553 of (2008), it is the actual scarcity of a factor input which halts the production process and causes the crises. This is unavoidable no matter what form the denouement takes.

Huerta de Soto states that these stages are constitutive of the structure of the expansion, which must therefore end in crisis. He warns that in particular stages 5 and 6 must not be interfered with if recovery is to be swift:

The errors and recession could persist indefinitely... rigidity is the chief enemy of recovery and any policy aimed at mitigating the crisis and initiating and consolidating recovery as soon as possible must centre on the micro-economic goal of deregulating all factor markets, particularly the labour market.. (Huerta de Soto [2008] p. 435).

In contrast, it is worth reviewing the 6 micro-economic factors with respect to an economic expansion driven by real savings.

1. There is no relative increase in the capital values of factors of production furthest away from consumption:

On the contrary, if loans originate from an upsurge in real saving, the relative decrease in immediate consumption which this saving inevitably entails frees a large volume of productive resources in the market of original (earlier stage) means of production... there is no need to pay a higher price for them. (Huerta de Soto [2008] p. 398).

As actual resources are released to these stages the entrepreneur is not placed in the position he was during credit inflation, when he had to bid higher for a static number of factors.

2. There is a drop in the price of consumer goods in the short term, as saving implies less demand for such goods. 
3. Therefore, no relative accounting increase in the profits of those industries closest to consumption.

4. Nor a decrease in the profits of stages furthest from consumption.

5. The «Ricardo Effect» is oppositely experienced to the case of credit expansion as real wages rise and entrepreneurs are incentivised to increase investment in machines therefore. Although some disruption may be experienced in specific sectors, any labour released is available for utilisation in the greater range of economic opportunities caused by the strengthening production structure. As, in for example, $19^{\text {th }}$ Century Britain, there are often labour shortages. Reisman (1998) has shown that Labour is in fact the only permanently «ineradicable» scarce factor in conditions of freedom. (Reisman [1998] pp. 59-61).

6. Market rates of interest tend to decline permanently. Saving implies a lower time preference which is constitutive of lower interest rates. The fall in the price of consumer goods increases the purchasing power of money and financial stability lowers risk premiums.

The PPF moves rightwards.

\section{REMEDIES}

In this section we shall look at the proposed policies which aim at remedy and prevention of such crisis as we have described. Perhaps the most important thing to point out, in sharp contrast to all other schools of thought, the Austrians believe the depression phase is a period of remedying the distortions caused by credit inflation which should be allowed to run its course. We have seen Huerta de Soto proselytize for a policy of maximum flexibility to factor markets. Similarly, Rothbard (1993):

the crisis-depression phase is the curative period... the time when bad investments are liquidated and mistaken entrepreneurs leave 
the market... The depression period ends when the free market equilibrium has been restored and expansionary distortion eliminated.

Since the depression period is the recovery process, any halting or slowing of the process impedes the advent of recovery. The depression readjustments must work themselves out before recovery can be complete. (Rothbard [1993] p. 860).

We shall now turn to a challenge to this position, particularly associated with Keynes.

\section{Economic collapse to within the PPF}

This is the assertion, which indeed we do appear to observe evidence for in every serious contraction, that it is not just the malinvested businesses and entrepreneurs that fail and must liquidate: this is a completely widespread phenomenon which includes otherwise perfectly sound businesses which suffer from the period of disruption to such an extent that they fail also, and create a snowball effect of economic destruction. Closely tied to this view is the, again, Keynesian/Monetarist idea that reflation would be the lesser evil to allowing the crash to continue, as it provides the liquidity/bank credit and working capital necessary to the survival of sound companies, as well as the bad ones (and lowers real wages via further currency debasement, acting against unemployment). Even more so, such a viewpoint supports the «bailing out» of economically significant companies such as in the automobile industry, airlines and capital goods markets in order to minimise damage, as they put it, to the sustainable economic process distinct from the structure of mistaken investment, but now vulnerable to effects attendant to their liquidation.

Hayek recognised the possibility of "secondary depression" and Mises discusses the role played by unemployed factors in Human Action XX.9.

Garrison describes this possibility in terms of a movement of the economy well within the PPF: 
History suggests that there is a real danger, especially in the face of ill-conceived policy actions by the monetary authority... that the recovery phase will be pre-empted by spiralling down into deeper depression... moving to successively lower levels of both consumption and investment despite its already having fallen below the PPF. This is the aspect of the downturn that concerned Keynes in his General Theory. (Garrison [2004] p. 341).

While being fully cognisant of both this possibility and its attendant suffering, I think it can be decisively shown that nevertheless, any attempt to alleviate this suffering and save sound businesses is utterly misconceived.

Firstly, no-one knows which businesses, especially in industrial sectors at the epicentre of the crash, but more generally, are sound. They by definition are not led by management that have thought it wise to invest in reserves.

Even if this is harsh, shoring up the economy in general will allow unsound businesses to perpetuate, and will do absolutely nothing to ease resource constraints which precipitated the crisis in the first place. The economic distortions can only grow in such a policy, and like drinking salt water, must end in total collapse.

We must not be mislead either by such language as «economic destruction»: the capital goods of «sound» businesses are not actually destroyed and there is no basis for the belief that the long term potential of the economy is damaged if these companies fail.

In fact, neither is there any basis for the belief that the economy has fallen to within the PPF, rather the PPF may have moved leftward due to the crisis and waste of resources beforehand, so that even in the terms of the argument, any attempt to restore the old position would be hopeless.

The most damning indictment of this policy is that it cuts off or distorts the very price signals, yet again by a process of inflation, which actors in the economy require in order to restore it to the PPF. In fact, these price signals are the only means by which resources erroneously invested in certain areas can be liquidated and re-assigned properly. (Huerta de Soto [2009] p. 236).

Only economic recovery can ensure sustainable levels of full employment: driving down real wages by inflation is not sustainable. 
The relative fall in the prices of consumer goods eases the suffering as money buys more per unit.

We therefore must conclude that the only rational policy response is complete laissez faire as stated and implied by Rothbard and Huerta de Soto.

\section{Prevention of crisis and reform of the banking system}

In essence, Mises states the solution elegantly:

What is needed to prevent any further credit expansion is to place the banking business under the general rules of commercial and civil laws compelling every individual and firm to fulfil all obligations in full compliance with the terms of the contract. (Mises [1998] p. 440).

Banking is privileged from such laws, by which Mises means, and Huerta de Soto (2008) repeatedly emphasises, traditional legal principles which outlaw the banking system making use of the property deposited with them for their own ends, becoming insolvent at that point, though its only when this is noticed that there is a withdrawal crisis, as individuals scramble for their money. In fact, to prevent this is the chief role of the central bank: its role as «lender of last resort». In other words, it is intended to support a policy of continual inflation by attempting to ensure that enough reserves are printed to keep the banking system in operation, by shoring up the balance sheets of commercial banks when they face a default. In fact such an institution creates enormous incentives to expand which constitute «moral hazard», ie the protection from bad consequences of foolish action encourages that action.

Earlier Mises had emphasised the essential requirement of 100\% reserves:

The main thing is that the government should no longer be in a position to increase the quantity of money in circulation and the amount of chequebook money not fully-that is 100 percentcovered by deposits paid in by the public. (Mises [1912] p. 481). 
No bank must be permitted to expand the total amount of its deposits subject to cheque or the balance of such deposits... This means a rigid 100\% reserve for all future deposits... (Mises [1912] p. 491).

\section{Similarly Hayek:}

The problem of the prevention of crises would have received a radical solution... (by)... the prescription of 100 percent gold cover for bank deposits as well as notes. (Hayek [1984] p. 29).

Here, Hayek refers to the 1844 Peel Act in England which attempted to ensure a $100 \%$ reserve standard, but only applied it to banknotes, not realising that deposit accounts would be created aggressively, expanding the money supply.

Hayek doesn't worry about the broken hearts within the current banking system, though a $100 \%$ reserve requirement would greatly diminish their short term profitability:

An institution which has proved as harmful as fractional reserve banking without the responsibility of the individual bank for the money (i.e. cheque deposits) it created cannot complain if support by a government monopoly that has made its existence possible is withdrawn. (Hayek [1978] pp. 94-95).

We can see from the FDIC's (Federal Deposit Insurance Corporation) reserve classifications just how far from this ideal we currently are. These are the capital ratios for bank reserves.

- Well capitalized: $10 \%$ or higher

- Adequately capitalized: $8 \%$ or higher

- Undercapitalized: less than $8 \%$

- Significantly undercapitalized: less than $6 \%$

- Critically undercapitalized: less than $2 \%$

Source: FDIC website.

Even the so-called «well capitalised» banks can lose their entire reserve in a single economic contraction which may see asset prices fall by up to $30 \%$, given historical experience, in the short 
term (e.g. UK property prices in the early 1990s and the 1987 Stock Market crash.) State deposit Insurance agencies, such as the FDIC, do not have the resources to guarantee bank deposits if there is such a severe contraction and the press noted in 2009 that the FDIC only held assets equal to about $1.5 \%$ of the total possible insurance liability.

Hayek (1978) also famously called for the complete privatisation of money going so far as to suggest disparate competing currencies. (However, Huerta de Soto argues that Hayek...

... gives insufficient recognition of the fact-central to Mises's theory of money-that free market money must be a commodity money, and that competing kinds of money are dysfunctional to the very purpose of a medium of exchange, as the free market always generates a tendency to converge toward one, universally employed commodity money. (Huerta de Soto [2009] p. 308).

Rothbard (2005b) makes a case for a 100\% reserve gold based system with a practical prescription for rebasing bank reserves with gold at an equivalence value of the total gold reserves of the government to the current total money supply-a move which would create a massive windfall for the banks as Rothbard recognises, though it is a price he is prepared to pay for future stability.

We do not have space to fully consider arguments for what is called free banking, which makes the assumption that purely market forces will move the bank system towards higher and higher reserve requirements, that additional money is demanded by the market and that this is a contractual matter between banks and their customers anyway. It may be argued that not having a $100 \%$ reserve constitutes fraud and cannot be tolerated at all in a free market, but the essential point is the recognition that it is the nature of fractional reserve that constitutes the inflationary threat.

Finally, Huerta de Soto (2008) presents what I believe is the most developed and encompassing recommendations for reform based on total freedom of choice in currency-i.e. the complete privatisation of money and abolition of legal tender laws, likely to result in a gold or silver currency standard - and a system of complete banking freedom based on $100 \%$ reserve requirements. 
(Experience in the $19^{\text {th }}$ Century demonstrates that a gold standard on its own is not sufficient to prevent credit expansioncredit can be pyramided on the back of gold reserves.)

As Huerta de Soto states-

a defence of free banking does not imply permission for banks to operate on any fractional reserve. (Huerta de Soto [2008] p. $740)$.

In fact, elsewhere, Huerta de Soto critically dismisses the fractional reserve free banking arguments of economists such as George Selgin, who believe that fractional reserve private banks won't generate economic cycles because they only respond to demand on the part of the public. (Huerta de Soto [2009] p. 149). As we have stated earlier, in relation to Huerta de Soto (2009) p. 154 , the new money enters the economy at points quite distinct from where it may be demanded by «the public» and the banking system is motivated to create demand as well as respond to it, to "push» credit, because of the profitability of loans-that is the problem is both exogenous and endogenous (Huerta de Soto [2009] pp. 137-168). In addition, Huerta de Soto emphasises that any fractional reserve system would in itself constitute a breach of public order-i.e. would directly harm third parties, via currency debasement, and the matter cannot therefore be a contractual position between banks and individuals as Selgin argues. (Huerta de Soto [2009] p. 165).

Huerta de Soto calls for the elimination also of the central banks in order to avoid the problems of moral hazard noted above.

Huerta de Soto goes further and suggests that the assets of the banking system, as they are basically the proceeds of plunder via inflation, should be used, for example, to pay down the national debt and finance the social costs of transition. This strikes me as a great improvement on Rothbard's suggestion.

We should note, although this is implicit in our support that properly credit should be backed fully by savings, that the imposition of $100 \%$ reserves on the banking system in line with traditional legal principles, does not deprive industrial expansion of necessary funds. Only savings backed credit can provide 
sustainable development which will not be exposed as a mirage in a crisis, actually with resultant net losses. (Huerta de Soto [2008] p. 749).

\section{The pragmatic suggestions of Alonso, Bagus and Rallo (2012)}

The most serious danger to all reform programs lies in the political pragmatism of daily affairs, which often causes authorities to abandon their ultimate goals on the grounds that they are politically impossible... (Huerta de Soto [2008] p. 788).

One can imagine the enormous political and special interest resistance to such proposed reforms as we have seen, especially given our analysis of the incentives behind the current symbiosis of government and banks.

It is in this light that authors Miguel Alonso, Philipp Bagus and Juan Ramón Rallo presented what might be termed a more pragmatic set of policy recommendations (Alonso et al. [in press 2012]). In fact, Alonso et al.'s paper can be seen as a concrete example of the advice given by Huerta de Soto in his paper «Hayekian Strategy to implement free market reforms.» (Huerta de Soto [2009] pp. 182-199). Huerta de Soto emphasises a so-called «dual stategy»:

First, the essential principles of free market theory should be studied, defining the final goals which it is intended to attain in the long term... At the same time, in the shorter term, a policy to bring us closer to these goals can and should be designed, remembering that this... must also be consistent with them. (Huerta de Soto [2009] p. 188).

That is, nothing must be done which contradicts the essential principles though a shorter term policy may only partially realise it.

This envisages leaving current monetary authorities in place but paying much more attention to asset prices-such as stock 
market and real estate indices, and perhaps capital goods indices. This is on the grounds that-

without credit expansion, such asset bubbles are unlikely to develop. In the absence of credit expansion, savings flow slowly and steadily to the stock market. The incentives to liquidate and engage in stock market investments tend to balance. If the price of a stock is below its net present value, entrepreneurs will buy the stock, while they will sell it if it is over its net present value. (Alonso et al. [in press 2012].)

Similarly, Fritz Machlup claims

If it were not for the elasticity of bank credit... the boom in security values could not last for any length of time. (Machlup [1940] p. 92).

And again Huerta de Soto:

Therefore (and this is one of the most important conclusions we can reach at this point) uninterrupted stock market growth never indicates favourable economic conditions. (Huerta de Soto [2008] p. 462). This is although-

... rise in saving will stimulate growth in the price of securities, which will indicate the recovery has begun and entrepreneurs are again embarking on new processes of investment in capital goods. Nonetheless the upturn in stock market indices will not be spectacular as long as new credit expansion is not initiated. (Huerta de Soto [2008] p. 465).

Hence Alonso et al. conclude:

If, as soon as there speared signs of a general boom on security markets, the central banks were to take action to bring it to an end, it seems probable that extremes of business fluctuations might be avoided. (Alonso et al. [in press 2012]).

Alonso et al. also recommend that the central bank should raise interest rates and restrict credit until the boom stops. In addition, and in general, central banks should only purchase the highest 
quality assets and lend money to the banking system only at penalty interest rates to dis-incentivise credit expansion. (Alonso et al. [in press 2012].)

These recommendations are well intentioned, but I believe suffer from several flaws, the main one of which is that the institutions left in place are incentivised, for the reasons we mentioned earlier, to remove all these restrictions, which they shall certainly do.

However, even if they did not, the likely result of following these policies would indeed be an avoidance of boom but at the price of pushing the economy permanently within the PPF.

Firstly, if the recommendations are put in place following a previous bust so the economy is already within the PPF, simple recovery to the PPF, if it appears as an extended but above trend growth rate in securities values as confidence returns, will be seen as a new boom and genuine recovery will be at risk of getting choked off.

Secondly, although Huerta de Soto's et al.'s contentions that security prices can never healthily display pronounced and prolonged upward movements is correct if «pro-longed» is understood as an a-terminal trend, nevertheless there is no problem with envisaging a long, completely legitimate expansion, driven by a falling demand for money against security prices, or perhaps financed by sales in the very much larger bond market taking place over a long period.. Stock market indices can, in the aggregate, be driven higher by positive change in just one constitutive sector-perhaps in line with technological innovation increasing productivity, with the removal of regulation (i.e. for completely non-monetary reasons) or perhaps by the emergence of completely new markets.

Securities prices changes depend upon the valuations of the marginal pair effecting a transaction. (Menger [1870] chapter. 5). These can constitute a series of exchanges at rising prices, logically independently of overall money supply taken in isolation, though not when taken together with regard to changes in the volume of transactions in the economy as a whole.

Epistemologically, by which I mean here "given what we know», these changes are random ex ante. (In Nassim Taleb's formulation 
«Randomness is fundamentally incomplete information.» Taleb [2007] p. 198). «What is random and what you do not know are functionally the same.» (Taleb [2004] p. 258). It is possible that a series of such changes can be experienced, entirely at random, giving rise to a prolonged rise in prices. In fact, this is a certainty and may in fact occur very frequently. If there is a 50/50 chance of the market's rising or falling each trading day, it is certain that prolonged trends will occur. When we further consider that such trends are based around what should be a rising underlying trend, because of quite normal capital accumulation coupled with, for example, new foreign investment or a switch from the bond market, business results may exhibit a strong upward character for extended time periods.

Rothbard hits the nail on the head:

It is... absurd to expect business activity to be «stabilised» as if these changes were not taking place. To stabilise and «iron out» these fluctuations would, in effect, eradicate any rational productive activity. (Rothbard [2005] p. 5).

I believe that the error here is exactly that of socialism-that centralised knowledge of the economy can be gathered by indicators and appropriate policy devised. Scrutinising asset price movements may reveal an unsustainable boom or it may be due to sound changes in the reality, or both. The point is that centralised authorities not only cannot know but will distort the signals themselves by acting coercively in regard to them.

If one wants to know whether or not there is credit expansion, one must look at the state of the supply of fiduciary media, not at the arithmetical state of interest rates. (Mises [1998] p. 557). A fortiori, one cannot look either at the state of stock market indices.

The only solution seems to be the radical suggestions leading to the removal of the central bank, the complete overhaul of banking and the privatisation of money, that we have discussed. 


\section{$\mathrm{V}$ \\ CONCLUSION}

We have situated the Austrian Theory of the Business Cycle within the framework of Austrian intellectual contributions by showing it to be concerned with a practical example of the socialist calculation problem.

We began by identifying the business cycle as caused by aggressive manipulation of the monetary system and interest rates, carried out in a state of ignorance of society's true resources, and institutional aggression in the form of fractional reserve banking-this causes inflation and the consequent interference with the market price system, which alone can transmit accurate signals to market participants as to the configuration and utilisation of resources. We used Roger Garrison and other writer's recent work to present a modern, but simplified account of ABCT.

We then considered the differences and similarities between the most important developers of the theory historically, Ludwig von Mises and F.A. Hayek, by focusing on some key terms such as «Forced Saving», «Malinvestment», «Overconsumption» and «Overinvestment».

On the basis of the entire preceding analysis, we proceeded to examine policy aimed at the prevention and cure of the boombust cycle, including the "pragmatic» suggestions of Alonso et al. of a step in the direction of preventing booms by monitoring asset prices. In rejecting this, we came to the conclusion that the only solution is the radical one suggested by authors such as Huerta de Soto (2008).

And indeed such a radical solution is very urgent. The recent crisis saw the near collapse of the entire world banking system despite the frantic and co-ordinated efforts of each country's «lender of last resort.» A sudden and dramatic deflation (in the form of worldwide banking collapse) still threatens and indeed, in line with ABCT, eventually seems probable. The experience of 2008 was that the best efforts of the state to shore up the banking system by printing «liquidity» nearly failed and many have questioned the adequacy of the resources of deposit insurers such as the FDIC. (For example, the Wikipedia entry on the FDIC: 
In light of apparent systemic risks facing the banking system, the adequacy of FDIC's financial backing has come into question. Beyond the funds in the Deposit Insurance Fund above and the FDIC's power to charge insurance premia, FDIC insurance is additionally assured by the Federal government. According to the FDIC.gov website (as of January 2009), «FDIC deposit insurance is backed by the full faith and credit of the United States government». This means that the resources of the United States government stand behind FDIC-insured depositors. «The statutory basis for this claim is less than clear». Congress, in 1987, passed a non-binding «Sense of Congress» to that effect, but there appear to be no laws strictly binding the government to make good on any insurance liabilities unmet by the FDIC.)

It is not true that institutions such as the FDIC have ended the experience of bank failure. Their website lists many dozens of failures in only the last 3 years. This list suggests just how close the US economy came to a cataclysmic deflation in the form of systemic bank collapse. The only instrument available to the state to avoid this was further inflation. Hence, the outcome of credit expansion, although not predictable, in terms of which of either catastrophic expansion or collapse of the money supply will bring it to an end, puts the entirety of society at risk of fundamental economic breakdown.

Ayn Rand's identification of the necessity of a process of continuous production backing up the monetary system, essentially requires economic co-ordination via sound money and price signals. A continual utilisation and tolerance of inflation therefore threatens to stop the heart of this process, on which our lives depend.

\section{BIBLIOGRAPHICAL REFERENCES}

Allais, M. (1993): «Les conditions monetaires d'une economie de marches: des enseignments du passé aux reformes de demain», Paris, Revue d'economie politique 3, May-July.

Alonso, M.; Bagus, PH.; and Rallo, J.R. (2012): «The First Financial Crisis of the $21^{\text {st }}$ Century: Origins and Proposals 
for Reform. An Austrian Approach.» Interdisciplinary Journal of Economics and Business Law, Volume 1, Issue 4. Forthcoming.

CABLE, V. (2009): The Storm. London: Atlantic Books.

Denson, J. (2009): The Costs of War-America's Pyrrhic Victories. $2^{\text {nd }}$ expanded edition, New Jersey: Transaction Publishers.

Huerta De Soto, J. (2010): Socialism, Economic Calculation and Entrepreneurship. Cheltenham, UK: Edward Elgar.

- (2007): The Austrian School. Northampton MA: Edward Elgar Publishing.

- (2008): Money, Banking and Economic Cycles. 2 ${ }^{\text {nd }}$ Edition, Auburn Alabama: Ludwig Von Mises Institute.

- (2009): The Theory Of Dynamic Efficiency. Routledge Foundations of The Market Economy, New York: Routledge.

Friedman, M. and SchWARTZ, A.J. (1971): A Monetary History of The

United States, 1867-1960. Princeton: Princeton University Press.

GARRISON, R. (2004): «Overconsumption and Forced saving in the Mises-Hayek Theory of the Business Cycle». Durham, North

Carolina: History of Political Economy 36: 2, pp. 323-349.

GARrISON, R. (2001): Time and Money: the Macroeconomics of Capital

Structure. Foundations of the Market Economy series. New York: Routledge.

GotTFRIED, P. (2009): Is Modern Democracy Warlike? In Denson (2009). HAYeK, F.A. vON (1935): Prices and Production. $2^{\text {nd }}$ revised edition.

New York: Routledge and Kegan Paul.

- (1976): The Pure Theory of Capital. New York: Routledge and Kegan Paul.

- (1978): Denationalisation of Money. The Argument Refined. London: Institute of Economic Affairs.

- (1984): Money, Capital and Fluctuations: Early Essays. Chicago: University of Chicago Press.

HicKs, J. (1979): «The Hayek Story». In Critical Essays in Monetary Theory, pp. 203-215, Oxford: Oxford University Press.

Hume, D. (1985): Essays: Moral, Political and Literary. E.F. Miller ed., Indianapolis Indiana: Liberty Classics.

Machlup, F. (1940): The Stock Market, Credit and Capital Formation. Glasgow: William Hodge. 
Menger, C. (1981, 1870): The Principles of Economics. New York: New York University Press.

- (1892): «On the Origins of Money». Economic Journal, Volume 2, pp. 239-255. Translated by C.A. Foley.

Mises, L. von (1912, [1978]): Theory of Money and Credit. English Translation, Indianapolis Indiana: Liberty Classics.

- (1998): Human Action. Scholars Edition, Auburn Alabama: Ludwig Von Mises Institute.

MurPHY, R.P. (2008): Human Action Study Guide. Auburn Alabama: Ludwig Von Mises Institute.

RAND, A. (1982): «Egalitarianism and Inflation». In Philosophy: Who Needs It? pp. 120-136. New York: Signet Group.

ReIsMAN, G. (1998): Capitalism. Ottawa Illinois: Jameson Books.

Rothbard, M.N. (1993): Man, Economy, and State. Auburn Alabama: Ludwig von Mises Institute.

- (2005a): America's Great Depression. Auburn, Alabama: Ludwig von Mises Institute.

- (2005b): The Case for a 100 Percent Gold Dollar. Auburn, Alabama: Ludwig von Mises Institute.

- (2005c): What Has Government Done to Our Money? Auburn, Alabama: Ludwig von Mises Institute.

- (2008): The Mystery of Banking. Auburn, Alabama: Ludwig von Mises Institute.

SALERno, J. (2009): War and the Money Machine: Concealing the Costs of War beneath the Veil of Inflation, in Denson (2009).

SCIABARra, C.M. (2000): Total Freedom. Towards a Dialectical Libertarianism. Pennsylvania: Pennsylvania State University Press.

Strigl, R. von (2000): Capital and Production. Auburn, Alabama: Ludwig von Mises Institute

Taleb, N.N. (2004): Fooled by Randomness. New York: Random House.

- (2007): The Black Swan. New York: Random House. 